\title{
Biological Grandparent
}

National Cancer Institute

\section{Source}

National Cancer Institute. Biological Grandparent. NCI Thesaurus. Code C100806.

A biological parent of the biological father or biological mother. 